\title{
Study of Biological Characteristics of Pseudomonas aeruginosa Strains Isolated from Patients with Cystic Fibrosis and from Patients with Extra-Pulmonary Infections
}

\author{
Eliana Guedes Stehling, Wanderley Dias da Silveira and Domingos da Silva Leite \\ Department of Microbiology and Immunology, Institute of Biology, State University of Campinas (UNICAMP); Campinas, SP, Brazil
}

\begin{abstract}
A total of 120 strains of Pseudomonas aeruginosa, isolated from cystic fibrosis $(\mathrm{CF})$ patients $(\mathrm{n}=\mathbf{8 0})$ and from patients having extra-pulmonary infections $(n=40)$ were studied regarding the presence of some virulence factors (hemolysin, gelatinase and elastase production) and presence of the $\operatorname{alg} D$ and $\operatorname{alg} U$ genes as detected by polymerase chain reaction-PCR. There was not a significant difference for the production of gelatinase and hemolysin between nonmucoid strains from CF patients and other isolates from extra-pulmonary infections and mucoid strains. The production of elastase was found to be significant among these strains. The algD gene was detected by PCR in all studied strains but the alg $U$ gene was detected only in $25 \%$ of the mucoid strains. Conclusion withdrawn from the results were: (i) hemolysin and gelatinase production although present in many strains of $P$ aeruginosa should not be considered as general virulence factors for the mucoid phenotype but could help in the pathogenic process; (ii) elastase production could be a necessary virulence factor for the initial pathogenesis process; (iii) mucoid and nonmucoid phenotypes could also be expressed according to the host's tissues or environment, and finally, (iv) more than one regulator system for alginate production is probably present in each strain.

Key-Words: Pseudomonas aeruginosa, biological characterization, pathogenesis, cystic fibrosis, extra-pulmonary infections.
\end{abstract}

Pseudomonas aeruginosa is the bacterium most frequently associated with pulmonary infection in patients with cystic fibrosis $(\mathrm{CF})$, being the major infectious cause of morbidity and mortality in these patients [1-5]. This bacterium remains in the airways of the $\mathrm{CF}$ patients despite of intensive antibiotic therapy and contributes to the pulmonary failure. Following colonization of the respiratory tract of the CF patients with $P$. aeruginosa, the mucoid variant of the original strain emerges and becomes predominant [6,7], leading to chronic pulmonary infection indicating that this bacterial colony type has virulence traits that are important for the maintenance of the infection, what leads toward a poor prognosis for the patients [2,7].

$P$. aeruginosa produces a variety of extracellular enzymes that contribute to its pathogenesis [8-11]. The exoenzymes: alkaline protease [12], elastase [13], exotoxin A, exoenzyme S and hemolysin are produced during the course of clinical infection and contribute for the development of infections in animal models $[10,11,14]$. The proteolytic enzymes help to break down physical barriers of the host [15] and hemolysin lyses cells from varied sources. The expression of these exoproducts does not occur until the late logarithmic phase of growth, when the cell density is higher. This production occurs through a phenomenon called quorum sensing that is involved in the activation of genes at high cell densities in response to chemical signals released by $P$. aeruginosa [16].

Other virulence factors include pilus expression and alginate production. The pili from $P$. aeruginosa were Received on 30 August 2007; revised 19 January 2008.

Address for correspondence: Dr.Wanderley Dias da Silveira. Departamento de Microbiologia e Imunologia, Instituto de Biologia, CP 6109. Universidade Estadual de Campinas (UNICAMP). Cidade Universitária Zeferino Vaz de Almeida, Barão Geraldo, Campinas, SP, Brazil. Zip code: 13081-862. E-mail: wds@unicamp.br. Telephone: (0XX19) 3521-6268. Fax: (0XX19) 3521-6276.

The Brazilian Journal of Infectious Diseases 2008;12(1):86-88. (C) 2008 by The Brazilian Journal of Infectious Diseases and Contexto Publishing. All rights reserved. associated to adhesion and binding to $\mathrm{GM}_{1}$ receptors on the surface of CF epithelial cells [17,18]. The pilus (type IV) genes responsible for these processes are all located in the bacterial chromosome and DNA sequencing revealed the presence of three open reading frames designated pilB, pilC, and pilD that encode proteins of 62,38 and $32 \mathrm{KDa}$, respectively [18]. Alginate is a viscous exopolysaccharide consisting of Dmannuronic and L-guluronic acids [10,19,20]. It prevents both opsonic and non-opsonic phagocytosis, protecting the bacterium cell from the host immune response [7].

The majority of enzymes involved in synthesis and modifications of the alginate polymers are encoded by a large cluster of genes located at $34 \mathrm{~min}$ of the $P$. aeruginosa chromosomal map [21] that is transcriptionally regulated by the products of several genes located in the 9- to 13-min region of the chromosome [22]. It includes $\operatorname{alg} R$ and $\operatorname{alg} B$, two homologous genes [23,24]; algP, a histone-like protein [25]; $\operatorname{alg} Q$ and $\operatorname{alg} U[6,21,26]$. These genes have their effects in the expression of the critical algD gene encoding GDP-mannose dehydrogenase [2].

The objective of this study was to evaluate in a comparative way the expression of some virulence factors (hemolysin, gelatinase, elastase and presence of genes $\operatorname{alg} D$ and $\operatorname{alg} U$ as detected by polymerase chain reaction-PCR ) by $P$. aeruginosa strains isolated from patients with cystic fibrosis and strains isolated from patients with extra-pulmonary infections.

\section{Material and Methods \\ Bacterial Strains}

The $P$. aeruginosa isolates used in this study were obtained from patients with cystic fibrosis (40 mucoid and 40 nonmucoid strains) (Table 1) and from patients suffering from several other types of infections (blood, urine and oropharynge - 40 strains) attended at the Clinical Hospital of the Campinas State University (UNICAMP), Campinas, São Paulo, Brazil. P. aeruginosa strain PA 1802 was used as a positive control strain 
Table 1. Frequency and percentage of produced exoenzymes and presence of the algD e algU genes in $P$. aeruginosa strains isolated from cystic fibrosis patients and from extra-pulmonary infection sites

\begin{tabular}{lccccc}
\hline Strains & Hemolysin & Gelatinase & Elastase & AlgD & AlgU \\
\hline Mucoids & $21 / 40$ & $15 / 40$ & $18 / 40$ & $40 / 40$ & $10 / 40$ \\
& $52.5 \%$ & $37.5 \%$ & $45 \%$ & $100 \%$ & $25 \%$ \\
Non-mucoids & $22 / 40$ & $23 / 40$ & $32 / 40$ & $40 / 40$ & $9 / 40$ \\
& $55.0 \%$ & $57.5 \%$ & $80 \%$ & $100 \%$ & $22.5 \%$ \\
Extra-pulmonary & $19 / 40$ & $22 / 40$ & $33 / 40$ & $40 / 40$ & $9 / 40$ \\
& $47.5 \%$ & $55.0 \%$ & $82.5 \%$ & $100 \%$ & $22.5 \%$ \\
\hline
\end{tabular}

for the expression of all biological traits tested. The isolates were identified by colony pigmentation, grape-like odor, motility and biochemical tests [(carbohydrate fermentation $(-)$, citrate assimilation (+), lysine decarboxylase (-), indol (-), oxidase (+), beta-hemolysis on blood-agar (+) and DNAse (-)].

\section{Hemolysin Production}

The method to detect the hemolysin production employed sheep blood agar. The strains were streaked out onto the surface of blood agar plates and incubated for $18 \mathrm{~h}$ at $37^{\circ} \mathrm{C}$. The formation of a clear halo around the colony was indicative of the production of hemolysin [26].

\section{Gelatin Hydrolysis}

The gelatin hydrolysis was used to detect activity of proteolytic enzyme (gelatinase). Bacterial cells were inoculated via a straight-line inside of tubes containing nutrient gelatin. The tubes were incubated for $48 \mathrm{~h}$ at $37^{\circ} \mathrm{C}$ and after this period of time, the tubes were kept in a refrigerator $\left(8^{\circ} \mathrm{C}\right)$ to determine if the hydrolysis of gelatin (due to production of gelatinase) had occurred (liquefaction of the medium) [27].

\section{Elastolytic Activity}

Elastase production was observed in a Petri dish containing $1 \%$ elastin, $2 \%$ agar, and $0.03 \mathrm{M}$ tris (hydroxymethyl) aminomethane (tris) buffer. Bacterial cells grew $\left(48 \mathrm{~h}\right.$ at $\left.37^{\circ} \mathrm{C}\right)$ onto the surface of these Petri dishes and the elastolytic activity determined by measuring the clear halo produced on elastin agar after this incubation period [10].

\section{DNAAmplification}

PCR was used to detect the presence of the $\operatorname{alg} D$ and algU genes. Oligonucleotides were used to amplify fragments of $1.5 \mathrm{~kb}$ and $300 \mathrm{bp}$ for $\operatorname{alg\mathrm {U}}$ and for $\operatorname{alg\mathrm {D}}$, respectively. Oligonucleotides algD1 (5'-AAGGCGGAAATGCCATCTCC$3^{\circ}$ ), algD2 (5'-AGGGAAGTTCCGGGCGTTTG-3) [22], algU1 (5'- CGCGAACCGCACCATCGCTC- $\left.3^{\circ}\right)$ and algG2 (5'GCCGCACGTCACGAGC-3 $3^{\circ}$ ) [28] were used to amplify the $a l g \mathrm{D}$ and $a l g \mathrm{U}$ genes, respectively. All amplifications were performed in a programmable thermal cycler Gene Amp PCR system 9700 . The reaction mixture $(50 \mathrm{~mL})$ included $2 \mathrm{~mL}$ of DNA template, $0.1 \mathrm{mM}$ (each) dATP, dGTP, dCTP and dTTP, $0.75 \mathrm{mM} \mathrm{MgCl} 2$ and $1 \mathrm{U}$ of Taq DNA polymerase. Each PCR reaction comprehended 30 amplification cycles, each consisting of $94^{\circ} \mathrm{C}$ denaturation step $(30 \mathrm{~s})$, a $55^{\circ} \mathrm{C}(\operatorname{alg} D)$ and $60^{\circ} \mathrm{C}(\mathrm{alg} U)$ annealing step (30s), a $72^{\circ} \mathrm{C}$ extension step (1 min), ending with a 7 min extension at $72^{\circ} \mathrm{C}$. PCR products were visualized on $1.5 \%$ submersed agarose gel electrophoresis after ethidium bromide staining [29].

\section{Results and Discussion}

The frequency of production of the exoenzymes hemolysin, gelatinase and elastase by each bacterial group is shown in Table 1. Taking all together, 62 (51.7\%) of the strains produced hemolysin, $60(50.0 \%)$ produced gelatinase and $83(69.1 \%)$ exhibited production of elastase and overall there was not a significant difference of exoenzymes production among strains isolated from $\mathrm{CF}$ patients and strains isolated from other types of infections (Table 1).

Hemolysin production is considered to be an important virulence factor of $P$. aeruginosa as indicated by Matján et al. [30] and Woods et al. [31], but our results pointed out to a different picture since there was not a significant difference among mucoid and non-mucoid strains isolated from CF patients and strains isolated from other types of infection. Based on these results we would like to suggest that hemolysin production as a virulence marker for pathogenicity should be taken carefully since a large number of strains did not present this fenotype.

Although gelatinase production was different between mucoid strains and the other two groups (non-mucoid and other types of infection) it was not statistically significant ( $\mathrm{p}>0.01)$, as observed for the hemolysin production, and in the same point of view, gelatinase production should be taken carefully as a virulence marker. Although the lack of statistical significance for both characteristics, hemolysin and gelatinase production, the expression of them must be taken in account when pathogenicity characteristics are studied since they could be necessary for the basic maintenance for the colonization process and therefore the survival of bacteria in the host's tissues.

The elastase production showed different results. There was a significant difference $(p<0.01)$ between mucoid and the other two groups of strains, with mucoid strains producing it with a lower percentage, i.e, $45 \%$ by mucoid strains and $80 \%$ and $82.5 \%$ by non mucoid and strains isolated from extrapulmonary infections, respectively.

Since elastin is a basic component of lung tissues, as well as from other host's tissues, as those found in vases of the blood stream, elastase production could be a necessary trait for the establishment of the infectious process and maintenance of the 
infection. These results partially agree with those published by Woods et al. [31] who demonstrated the production of high levels of elastase by $P$. aeruginosa strains isolated from the lung of $\mathrm{CF}$ patients. On the other hand, most $(82.5 \%)$ of the strains isolated from extra-pulmonary infection sites also produced elastase, what was not observed by Woods et al. [31].

Alginate expression is related to the presence of an operon composed by many genes with the activation processes being regulated by many other genes (algR, algP, algB) [32] and $\operatorname{algU}$, mucA and mucB, which are very important for the existence of the mucoid trait, with the algD gene being responsible for the expression of the alginate capsule. In our results, the PCR reactions indicated the presence of the algD gene in $100 \%$ of the strains but the algU was found only in $25 \%$ of the mucoid strains, what indicates that in the strains that do not have this last gene (algU) other regulating genes must be present [30]. Also many non-mucoid strains $(22.5 \%)$ and strains isolated from extra-pulmonary infection sites $(22.5 \%)$ presented the algU gene, in despite of them being non-mucoid.

What we can conclude from the data discussed above is: (i) hemolysin and gelatinase production although present in many strains of $P$ aeruginosa should not be considered as general virulence factors for the mucoid phenotype but could help in the pathogenic process; (ii) elastase production could be a necessary virulence factor for the initial pathogenic process; (iii) mucoid and non-mucoid phenotypes could also be expressed according to the host's tissues or environment, and finally, (iv) more than one regulator system for alginate production is probably present in each strain.

\section{Acknowledgements}

This work was supported by Grant number 97/04814-8 from Fundação de Amparo à Pesquisa do Estado de São Paulo (FAPESP) and Grant number 155200/2006-3 from Consellho Nacional de Pesquisa (CNPq).

\section{References}

1. Giligan P.H. Microbiology of airway disease in patients with cystic fibrosis. Clin. Microbiol Rev 1991;4:35-51.

2. Govan J.R.W., Deretic V. Microbial pathogenesis in cystic fibrosis: mucoid Pseudomonas aeruginosa and Burkholderia cepacia. Microbiol. Rev 1996;60:539-74.

3. Koch C., Hoiby N. Pathogenesis of cystic fibrosis. Lancet 1993;341:1065-9.

4. Mahenthiralingam E., Campbell M.E., Speert D.P. Nonmotility and phagocytic resistance of Pseudomonas aeruginosa isolates from chronically colonized patients with cystic fibrosis. Infect. Immun 1994;62:596-605.

5. Roychoudhury S., Zielinski N.A., De Vault J.D., et al. Chakrabarty. Pseudomonas aeruginosa infection in cystic fibrosis: biosynthesis of alginate as a virulence factor. Antibiot Chemother 1991;44:63-7.

6. Martin D.W., Schurr M.J., Mudd M.H., et al. Mechanism of conversion to mucoidy in Pseudomonas aeruginosa into cystic fibrosis patients. Proc Natl Acad Sci USA 1993;90:8377-81.

7. Pedersen S.S. Lung infection with alginate-producing, mucoid Pseudomonas aeruginosa in cystic fibrosis. APMIS. 100 Suppl 1992;28:1-79.

8. Bandjee M.C.J., Lasdunski A., Bally M. et al. Production of elastase, exotoxina $\mathrm{A}$, and alkaline protease in sputa during pulmonary exacerbacion of cystic fibrosis in patients chronically infected by Pseudomonas aeruginosa. J Clin Microbiol 1995;33:924-9.
9. Lory S., Tai P.C. Biochemical and genetic aspects of Pseudomonas aeruginosa virulence. Curr Top Microb Immun 1985;118:53-69.

10. Morihara K. Production of elastase and proteinase by Pseudomonas aeruginosa. J Bacteriol 1964;88:745-57.

11. Nicas T.I., Iglewski B.H. The contribution of exoproducts to virulence of Pseudomonas aeruginosa. Can J Microbiol 1985;31:387-92.

12. Holder I.A., Neely N.A. The role of proteases in Pseudomonas infections in burns: a current hypothesis. Antibiot Chemother 1991;44:99-105.

13. Holder I.A., Neely N.A. Pseudomonas elastase acts as a virulence factor in burned hosts by Hageman factor-dependent activation of the host kinin cascade. Infect Immun 1989;57:3345-8.

14. Doring G., et al. Role of Pseudomonas aeruginosa exoenzymes in lung infections of patients with cystic fibrosis. Infect Immun 1985;49:557-62.

15. Britigan B.E., Hayek M.B., Doebbeling B.N., Fick R.B. Transferrin and lactoferrin undergo proteolytic cleavage in the Pseudomonas aeruginosa - infected lungs of patients with cystic fibrosis. Infect Immun 1993;61:5049-55.

16. Albus A.M. et al. "Vfr control of quorum sensing in Pseudomonas aeruginosa ". J Bacteriol 1997;179:3920-35.

17. Saiman L., Prince A. Pseudomonas aeruginosa pili bind to asialoGM $_{1}$ which is increased on the surface of cystic fibrosis epithelial cells. J Clin Invest 1993;92:1875-80.

18. Strom M.S., Lory S. Structure-function and biogenesis of the type IV pili. Annu Rev Microbiol 1993;47:565-96.

19. Evans L.R., Linker A. Production and characterization of the slime polysaccharide of Pseudomonas aeruginosa. J Bacteriol 1973; 116 :915-24.

20. Ohman D.E., Chakrabarty A.M. Genetic mapping of chromossomal determinants for the production of the exopolysaccharide alginate in a Pseudomonas aeruginosa cystic fibrosis isolate. Infect Immun 1981;33:142-8.

21. Darzins A., Chakrabarty A.M. Clustering of mutations affecting alginic acid biosynthesis in mucoid Pseudomonas aeruginosa. J Bacteriol 1985; 164:516-24.

22. Wozniak D.J., Ohman D.E. Transcriptional analysis of the Pseudomonas aeruginosa genes $\operatorname{alg} R$, $\operatorname{alg} B$, and $\operatorname{alg} D$ reveals a hierarchy of alginate gene expression which is modulated by algT. J Bacteriol 1994;176:6007-14.

23. Deretic V., Schurr M.J., Boucher J.C., Martin D.W. Conversion of Pseudomonas aeruginosa to mucoidy in cystic fibrosis: Environmental stress and regulation of baterial virulence by aternative sigma factors. J Bacteriol 1994;176:2773-80.

24. Deretic V., et al. The algR gene, which regulates mucoidy in Pseudomonas aeruginosa belongs to a class of environmentally responsive genes. J Bacteriol 1989; $171: 1278-83$.

25. Wozniak D.J. Integration host factor and sequences downstream of the Pseudomonas aeruginosa algD transcription start site are required for expression. J Bacteriol 1994;176:5068-76.

26. Martin D.W., Holloway B.W., Deretic V. Characterization of a locus determining the mucoid status of Pseudomonas aeruginosa: $A \lg U$ shows sequence similarities with a Bacillus sigma factor. J Bacterial 1993;175:1153-64.

27. Wilson E. D. Studies in bacterial proteases I. The relation of proteases production to the culture medium. J Bacteriol 1930;20:41-59.

28. Schurr M.J., Martin D., Mudd M.H., Deretic V. Gene cluster controlling conversion to alginate-overproducing phenotype in Pseudomonas aeruginosa: functional analysis in a heterologus host and in the instability of mucoidy. J Bacteriol 1994;176:3375-82.

29. Sambrook J., Fritsch E.F., Maniatis T. Molecular Cloning: a Laboratory Manual. New York, Cold Spring Harbor Laboratory Press. 2nd Edition, 1989.

30. Majtán V., Hoštacka A., Košiarová A., et al. The toxinogenicity of Pseudomonas aeruginosa strains. Journal of Hygiene, Epidemiology, Microbiology and Imunology 1991;35:217-24.

31. Woods D.E., Schaffer M.S., Rabin H.R., et al. Phenotypic comparasion of Pseudomonas aeruginosa strains isolated from a variety of clinical sites. J Clin Microbiol 1986;24:260-4.

32. Selvaraj U., Ohman D.E., Quarless R., et al. Phosphorylationindependent activity of the response regulators $\operatorname{alg} B$ and $\operatorname{alg} R$ in promoting alginate biosynthesis in mucoid Pseudomonas aeruginosa. J Bacteriol 1998;180:956-68. 